\title{
Antioxidant Properties of Bee Products Derived from Medicinal Plants as Beekeeping Sources
}

\author{
Alessandra Durazzo ${ }^{1, *(\mathbb{D}}$, Massimo Lucarini ${ }^{1}$, Manuela Plutino ${ }^{2}{ }^{(0)}$, Giuseppe Pignatti ${ }^{3}$, \\ Ioannis K. Karabagias 4,5 (D), Erika Martinelli ${ }^{6}$, Eliana B. Souto ${ }^{7}$, Antonello Santini ${ }^{8}$ (D) and Luigi Lucini ${ }^{6}$ \\ 1 CREA-Research Centre for Food and Nutrition, Via Ardeatina 546, 00178 Rome, Italy; \\ massimo.lucarini@crea.gov.it \\ 2 CREA-Research Centre for Forestry and Wood, 52100 Arezzo, Italy; manuela.plutino@crea.gov.it \\ 3 CREA-Research Centre for Forestry and Wood, 00166 Roma, Italy; giuseppe.pignatti@crea.gov.it \\ 4 Laboratory of Food Chemistry, Department of Chemistry, University of Ioannina, 45110 Ioannina, Greece; \\ ikaraba@uoi.gr \\ 5 Department of Food Science and Technology, School of Agricultural Sciences, University of Patras, \\ Charilaou Trikoupi 2, 30100 Agrinio, Greece \\ 6 Department for Sustainable Food Process, Università Cattolica del Sacro Cuore, Via Emilia Parmense, 84, \\ 29122 Piacenza, Italy; erika.martinelli1@unicatt.it (E.M.); luigi.lucini@unicatt.it (L.L.) \\ 7 CEB-Centre of Biological Engineering, University of Minho, Campus de Gualtar, 4710-057 Braga, Portugal; \\ eliana.souto@ceb.uminho.pt \\ 8 Department of Pharmacy, University of Napoli Federico II, Via D. Montesano 49, 80131 Napoli, Italy; \\ asantini@unina.it \\ check for \\ * Correspondence: alessandra.durazzo@crea.gov.it
}

updates

Citation: Durazzo, A.; Lucarini, M.; Plutino, M.; Pignatti, G.;

Karabagias, I.K.; Martinelli, E.;

Souto, E.B.; Santini, A.; Lucini, L.

Antioxidant Properties of Bee

Products Derived from Medicinal

Plants as Beekeeping Sources

Agriculture 2021, 11, 1136. https://

doi.org/10.3390/agriculture11111136

Academic Editors: Ilaria Marotti and Ângela Fernandes

Received: 22 July 2021

Accepted: 9 November 2021

Published: 13 November 2021

Publisher's Note: MDPI stays neutral with regard to jurisdictional claims in published maps and institutional affiliations.

Copyright: (c) 2021 by the authors. Licensee MDPI, Basel, Switzerland. This article is an open access article distributed under the terms and conditions of the Creative Commons Attribution (CC BY) license (https:/ / creativecommons.org/licenses/by/ $4.0 /)$.
Abstract: Plant species are fundamental source of nectar in beekeeping since bees access nectar and pollen from flowers. Consequently, bee products are strongly linked to the bee foraging flora source, and, depending on this, they acquire defined features, including their health and medicinal properties. Medicinal plants contribute greatly to increase the beneficial properties of bee products, such as honey, pollen, royal jelly, and propolis. Bee products represent a potential source of natural antioxidants that can counteract the effects of oxidative stress underlying the pathogenesis of many diseases. The antioxidant properties of bee products have been widely studied and there is an abundance of information available in the literature. Notwithstanding, the uniqueness of the presented perspective is to provide an updated overview of the antioxidant properties of bee products derived from medicinal plants as beekeeping sources. This topic is divided and discussed in the text in different sections as follows: (i) beekeeping and the impacts of environmental factors; (ii) an overview of the role of medicinal plants for bee products; (iii) definition and categorization of the main medicinal bee plants and related bee products; (iv) the study approach of the antioxidant properties; (v) the conventional and innovative assays used for the measurement of the antioxidant activity; and (vi) the antioxidant properties of bee products from medicinal plants.

Keywords: antioxidant properties; bee products; honey; propolis; plant sources; medicinal plants

\section{Introduction}

Bee products represent a potential source of natural antioxidants, including phenolic acids, flavonoids, and terpenoids as well as numerous other phytochemicals, which are capable of counteracting the oxidative stress effects underlying the pathogenesis of many diseases [1]. The main action of the antioxidants is based on the capability to inhibit oxidation processes, thus reducing the production of free radicals, which result in triggering a chain reaction, which may cause harmful cellular alterations [2]. Reactive oxygen species (ROS) are produced by living organisms as a result of the normal cellular metabolism and environmental factors. The ROS are highly reactive molecules involved in many cellular signaling pathways, and can damage cell structures, such as carbohydrates, lipids, nucleic 
acids, and proteins, and consequently alter their functions [3,4]. Oxidative stress is defined as a condition resulting when the critical balance between free radical generation and antioxidant defenses is unfavorable [5-7]. The state of oxidative stress could be related to various degenerative diseases, such as atherosclerosis, cancer, neurological disorders, diabetes, and cardiovascular disease [8,9].

The antioxidant compounds contained in bee products have different mechanisms of action causing the decrease of the adverse consequences of reactive oxygen and nitrogen species, which lead to oxidative stress. They can inhibit the enzymes responsible for producing superoxide anions and metal chelation, break the radical chain reactions, and play a preventive role inhibiting the formation of the reactive oxidants species [10]. The antioxidant properties of bee products have been widely studied for their relevant interest $[11,12]$. The current trend of interest in this topic is evident by the substantial amount and typology of the existing published research papers on bee products and antioxidants. For example, a search on honey throughout the Scopus online database was carried out by means of the string TITLE-ABS-KEY (honey* AND "antioxidant property" OR "antioxidant capacity " OR "antioxidant assay" ${ }^{* \prime}$. The "full records and cited references" were exported and processed using the VOSviewer software (version 1.6.16, 2020; www.vosviewer.com, accessed on 6 June 2021) [13-15]. The search returned 713 publications covering the time range from 1996 to 2021, and a total of 559 terms were identified and visualized as a term map in Figure 1. Figure 1 allows for the identification of the main terms to be correlated to research on the relationship between antioxidant properties and honey, and also identifies the main existing research lines focused on this topic. It is interesting to observe that among the top-recurring keywords, compounds such as phenols, flavonoids, phenol derivative, and polyphenols appear.

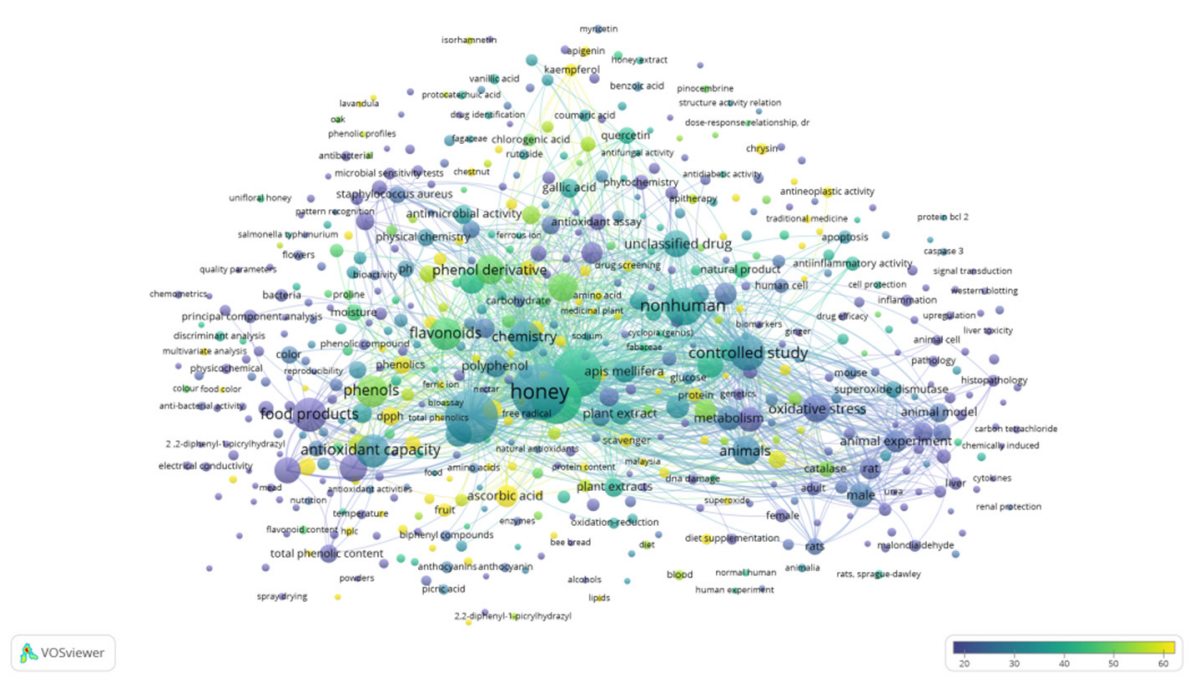

Figure 1. Term map for the relationship of honey and its antioxidant properties research. Bubble size represents the number of publications. Bubble color represents the citations per publication (CPP). Two bubbles are closer to each other if the terms co-appeared more frequently (bibliometric data were extracted from the Scopus online database and elaborated by the VOSviewer software).

Medicinal plants contribute greatly to increase the beneficial properties of bee products e.g., honey, pollen, royal jelly, and propolis, and have the potential to produce bee products with higher bioactivity. The value of honeybee products is strictly related to the plants that attract honeybees.

The uniqueness of this perspective is to provide an updated overview of the antioxidant properties of bee products derived from medicinal plants as beekeeping sources. The topic is discussed as follows: (i) beekeeping and the impacts of environmental factors; (ii) overview of the role of medicinal plants for bee products; (iii) definition and categorization of main medicinal bee plants and related bee products; (iv) study approach of the 
antioxidant properties; (v) conventional and innovative assays used for the measurement of the antioxidant activity; and (vi) antioxidant properties of bee products from medicinal plants. To our knowledge, these features have not been studied together in previous perspectives in the literature.

\section{Bee Products, Medicinal Plant, and Environment: An Overview}

An overview of the linkage of beekeeping, bee products, medicinal plants, and environment is delineated in the following sub-sections by underlining the key role of medicinal plants for bee products. The following topics are explored: (i) beekeeping and the impacts of environmental factors; (ii) overview of the role of medicinal plants for bee products; and (iii) definition and categorization of the main medicinal bee plants and the related bee products. The sizable contribution of medicinal plants to health properties of bee products is notable.

\subsection{Beekeeping and the Impacts of Environmental Factors}

Bees are considered significant pollinators due to their effectiveness and wide diffusion worldwide. Bee pollination provides excellent value to crop quality and quantity, improving global economic and dietary outcomes [16].

Honeybees (Apis mellifera) are social species and represent one of the most important pollinators for agricultural systems [17,18]. Humans have managed honeybees for thousands of years, and developed bee breeding for all continents, mostly the United States and Europe [19,20].

Bees have been used to produce honey and play a mandatory role in pollination since the time of Ancient Egypt populations [21,22]. Many centuries later, in the seventeenth and eighteenth centuries, the improvement of beekeeping techniques made it possible to maintain large bee colonies giving rise to modern apiculture [23].

In the United States and Europe, Bruckner et al. [24] showed that beekeepers faced significant seasonal problems, namely high mortality occurred over the winter. In the United States, beekeepers contain 30\% colony losses each winter. Other studies showed that seasonal floral resources, insecticide use, and the availability of natural environmental habitat are major drivers of bee health and abundance [25].

Honeybees are constituted by over 20,000 species and each colony contains thousands of individuals [26,27]. In Central Europe, the number of managed honeybee colonies have decreased since the 1960s [28,29].

This decrease in number could be attributed to bee activities, their survival and antropic impact on the eco systems are closely connected; humans depend on bees for ecosystem services and the bees depend on the antropic activities for their survival [30,31]. On the other hand, antropic impact and environmental pollution are main issues regarding honeybee survival, and in this regard, it should be considered that the life of many plant species depends on bee pollination. The reduction of bee colonies poses a serious risk to many plant species survival, and can also be considered a biomarker for human health $[32,33]$.

In an ecosystem global vision, recognizing several ecosystem services provided by bees is necessary, and so are the large variety of ecosystem services to humans, such as pollination, provision, regulation, and equilibrium [34]. If only one ecosystem service is considered, sharp declines in the provision of other ecosystem services may occur [35].

The honeybee is one of the most studied among all animals. This research has been almost entirely developed on the European honeybee Apis mellifera. According to the Food and Agriculture Organization (FAO) [36], only 11 new honeybee species have been recorded and identified in the past 15 years (Table 1 ). 
Table 1. Eleven honeybees species as recorded worldwide [36-38].

\begin{tabular}{cc}
\hline Genus & Species of Honeybees \\
\hline & Apis andreniformis \\
& Apis binghami \\
& Apis breviligula \\
& Apis cerana \\
Apis & Apis dorsata \\
& Apis florea \\
& Apis koschevnikovi \\
Apis laboriosa \\
Apis mellifera \\
Apis nigrocincta \\
Apis nuluensis
\end{tabular}

\subsection{The Role of Medicinal Plants for Bee Products: An Overview}

Plant species are fundamental in beekeeping as a source of nectar. The species visited by bees provide the honey with particular features: pleasant taste, typical color, and pharmaceutical beneficial properties. Honey is an exclusive vegetable product. About $80 \%$ of the world's population choose plant-based extracts for basic health care. The local population in many areas of the world uses medicinal plants holistically, and considers them an important source for the prevention and treatment of diseases, especially in low income countries where a conventional pharmacological approach may be difficult [39-42]. Honey is considered a therapeutic food, which possesses pharmacological activity [43].

The flora existing in the bees' environment is important for beekeeping since the bees collect nectar and pollen from flowers. The importance of flora in beekeeping has been observed by various authors around the world [44-46]. Plant species differ from place to place, in their flowering duration, due to climate, topography and agricultural practices. Knowing the type, density, and quality of bee flora are among the crucial factors for the success and productivity of beekeeping [47].

Forests, grasslands, agrophytocenoses (e.g., orchards, vineyards, flower crops), medicinal plant plantations, and aromatic herbs are frequently visited by bees to search for melliferous plants [48].

According to Bakour et al. [49], most beekeepers prefer plants characterized by several and numerous beneficial properties for the well-being of humans as antioxidant, antiinflammatory, antifungal, antidiabetic, diuretic, having effects in the cure of different types of cancer, and also in the neurodegenerative, cardiovascular, and gastrointestinal tract diseases. The medicinal properties of bee products are also dependent on their botanical sources, as previously reported [50]; the several botanical origins provide bee products with numerous medicinal properties and products with therapeutic features for consumers.

Some of the most popular bee products for positive human health characteristics have been reported [51-53]:

1. Bee pollen: is a product rich in B vitamins, minerals, and unsaturated fatty acids. Many metabolic difficulties may be overcome with bee pollen supplementation and also it counteracts harmful bacteria.

2. Propolis: is effective against bacteria and purifies or disinfects. Its use is recommended for the treatment of colds, wounds, or ulcers, and diseases affecting the joints.

3. Bee bread: is a bee pollen-derived product, which acts as an activator of beneficial properties for blood circulation, is capable of healing and strengthening the immune and nervous system, and enriches polyunsaturated fatty acids intake.

The aforementioned products are strongly linked to the vegetable source from which the bees acquire their properties, including health and medicinal properties.

The importance of medicinal plants for beekeeping not only refers to the possibility of obtaining bee products from these species. In beekeeping, for some time, medicinal plant species have also been used as an alternative to pesticides [54-56]. According to 
Khan et al. [57], many honey bee pathogens are contrasted with medicinal plants by beekeepers. Several medicinal plants are effective against fungi, mites as Varroa spp., and bacteria. Nguyen et al. [58] investigated physicochemical and viscoelastic properties of honey from medicinal plants, i.e., Tulsi, Alfalfa, and two varieties of Manuka honey derived from medicinal plants.

In the next section, bee products derived from medicinal plant sources are described and explored in detail.

\subsection{Definition and Categorization of Main Medicinal Bee Plants and Related Bee Products}

Many plants considered mainly as food or raw material sources have some special beneficial health effect [59-64]. Sage (Salvia spp.) leaves, for example, are the basis for an herbal tea, which can be used for medicinal purposes, but these are also used in food preparation as spices and seasonings (as an aromatic plant), while the essential oil is used in cosmetics (e.g., soaps, and toothpaste). In this sense, the term 'medicinal' is often understood in a wide sense, and includes several overlapping uses as herbal teas, spices, food, raw material, dietary supplements, and cosmetics containing extracts of derived compounds from plants [65].

The World Checklist of Useful Plant Species contains more than 40,000 taxon names from more than 400 families and 6000 genera with a documented human use [66]. Medicinal plants, both for human and veterinary use, account for 26,662 species, and this number constantly increases with research on uses in folk or traditional medicine systems and with the addition of new plant species. The exact number of species used as medicinal material in Europe is difficult to ascertain because of the limited amount of used material (which escape from trade catalogues), the origin from several (often undetermined) plant species and lack of documentation for local uses. About 2000 taxa commercially available are sources of medicinal and aromatic plant material, and two-third of them are represented by species native to Europe [65]. In particular, Germany (1500 taxa, 600 native), France (900 taxa, 450 native), and Spain (800, 600 native) are the leading countries in the trade of medicinal and aromatic plants in Europe.

The demand for wild-collected plants species is increasing worldwide, and has become a risk for the conservation and preservation of the natural resources [67]. Using data filtering from global checklists of medicinal plants, about 400 medicinal plant species native to Europe have been included in the European red list of medicinal plants [68]. For the species in which sufficient data are available, the $2.4 \%$ were assessed as threatened and the $4.5 \%$ near threatened, following International Union for Conservation of Nature (IUCN) Red List Categories. The highest number of species was found in the Mediterranean area and in mountain areas (e.g., Alps, Pyrenees, Massif Central, Balkan Peninsula), with a similar pattern for endemic plant species.

In the same study, the major threats have been identified as wild plant collection and loss of habitat (respectively, $26 \%$ and $30 \%$ of all species), connected to human impact, the so called anthropic effect (e.g., livestock farming, recreational activities, tourism, use of chemicals, pollution, and urban development).

Bee foraging activity on plants is dedicated to the search of nectar and honeydew as carbohydrate sources, pollen (as a protein source), and resins to produce propolis (for antimicrobial and defense purposes) [69]. Pollen is collected by the bees during their visits on the plant flowers and it is stored in pellets as a protein source into the hive. The botanical origin of both honey and pollen depends on the flora surrounding the area of foraging and influences physico-chemical, functional, and sensory properties of bee products [70-72].

More than half of the medicinal plant species of the European checklist might be considered as relevant nutrition sources for bees (Table 2). 
Table 2. Main plant taxon (family, genus) of the European medicinal plant red list in relation to bee foraging sources. $\mathrm{N}=$ number of species belonging to the shown genus or group $(\mathrm{W}=$ attractive plants for wild bees). Plant data from Allen et al. [68], bee preferences for pollen and nectar from MLR, [73], MAA, [74].

\begin{tabular}{|c|c|c|c|c|c|c|c|}
\hline Plant Family & N. & Nectar & N. & Pollen & Honeydew & N. & Wild Bees \\
\hline AMARYLLIDACEAE & 2 & Allium & 2 & Allium & & 2 & W \\
\hline ANACARDIACEAE & 1 & Cotinus & 1 & Pistacia & & & \\
\hline BETULACEAE & & & 2 & Betula & Betula & & \\
\hline BORAGINACEAE & 3 & $\begin{array}{c}\text { Borago, } \\
\text { Symphytum, Pulmonaria }\end{array}$ & 3 & $\begin{array}{c}\text { Borago, } \\
\text { Symphytum, Pulmonaria }\end{array}$ & & 3 & W \\
\hline CAPRIFOLIACEAE & 4 & Valeriana, Viburnum, Sambucus & 4 & Valeriana, Viburnum, Sambucus & & 2 & $\mathrm{~W}$ \\
\hline ASTERACEAE & 13 & $\begin{array}{l}\text { Arctium, Aster, Cichorium, } \\
\text { Taraxacum, Achillea, Inula, } \\
\text { Matricaria, Silybum, Solidago, } \\
\text { Tanacetum, Tussilago }\end{array}$ & 15 & $\begin{array}{l}\text { Arctium, Aster, Cichorium, } \\
\text { Taraxacum, Achillea, Inula, } \\
\text { Matricaria, Silybum, } \\
\text { Solidago, Tanacetum, } \\
\text { Tussilago, Helichrysum }\end{array}$ & & 8 & W \\
\hline CRUCIFERAE & 1 & Brassica & 3 & Brassica, Capsella, Lepidium & & 3 & $\mathrm{~W}$ \\
\hline CUPRESSACEAE & & & 4 & Juniperus & & & \\
\hline ERICACEAE & 7 & $\begin{array}{l}\text { Calluna, Erica, Vaccinium, } \\
\text { Arbutus, Rhododendron }\end{array}$ & 6 & $\begin{array}{c}\text { Calluna, Erica, Vaccinium, } \\
\text { Rhododendron }\end{array}$ & & 1 & W \\
\hline FAGACEAE & 1 & Castanea & 4 & Castanea, Quercus & $\begin{array}{l}\text { Castanea, } \\
\text { Quercus }\end{array}$ & 3 & $\mathrm{~W}$ \\
\hline IRIDACEAE & 7 & Iris & & & & 7 & W \\
\hline LAMIACEAE & 34 & $\begin{array}{c}\text { Hyssopus, Lavandula, Thymus, } \\
\text { Glechoma, Nepeta, Origanum, } \\
\text { Prunella, Rosmarinus, Salvia, } \\
\text { Teucrium, Galeopsis, Lamium, } \\
\text { Leonurus, Melissa, Satureja, } \\
\text { Stachys, Mentha }\end{array}$ & 34 & $\begin{array}{l}\text { Hyssopus, Lavandula, Thymus, } \\
\text { Glechoma, Nepeta, Origanum, } \\
\text { Prunella, Rosmarinus, Salvia, } \\
\text { Teucrium, Galeopsis, Lamium, } \\
\text { Leonurus, Melissa, Satureja, } \\
\text { Stachys, Mentha, } \\
\text { Clinopodium, Ballota }\end{array}$ & Thymus & 34 & W \\
\hline LEGUMINOSAE & 7 & $\begin{array}{l}\text { Melilotus, Trifolium, Medicago, } \\
\text { Astragalus, Ononis, Pisum }\end{array}$ & 6 & $\begin{array}{c}\text { Melilotus, Trifolium, Medicago, } \\
\text { Ononis, Pisum }\end{array}$ & & 7 & W \\
\hline MALVACEAE & 3 & Malva, Althaea & 3 & Malva, Althaea & & 1 & $\mathrm{~W}$ \\
\hline OLEACEAE & & & 3 & Fraxinus, Olea & Fraxinus & & \\
\hline ORCHIDACEAE & & & & & & 30 & W \\
\hline PAEONIACEAE & 3 & Paeonia & 3 & Paeonia & & & \\
\hline PAPAVERACEAE & & & 3 & Papaver, Chelidonium & & 3 & $\mathrm{~W}$ \\
\hline PINACEAE & & & 4 & Pinus, Abies, Larix & $\begin{array}{l}\text { Pinus, } \\
\text { Abies }\end{array}$ & & \\
\hline PLANTAGINACEAE & & & 6 & Plantago & & 5 & $\mathrm{~W}$ \\
\hline POLYGONACEAE & 1 & Polygonum & 4 & Polygonum, Rumex & & & \\
\hline PRIMULACEAE & 3 & Primula & 3 & Primula & & 2 & W \\
\hline RANUNCULACEAE & 7 & $\begin{array}{c}\text { Aquilegia, Helleborus, } \\
\text { Aconitum, Ficaria, Pulsatilla }\end{array}$ & 8 & $\begin{array}{c}\text { Aquilegia, Helleborus, } \\
\text { Aconitum, Ficaria, Pulsatilla, } \\
\text { Hepatica }\end{array}$ & & 2 & $\mathrm{~W}$ \\
\hline ROSACEAE & 15 & $\begin{array}{c}\text { Malus, Prunus, Rubus, } \\
\text { Agrimonia, Crataegus, Geum }\end{array}$ & 25 & $\begin{array}{c}\text { Malus, Prunus, Rubus, } \\
\text { Agrimonia, Crataegus, Geum, } \\
\text { Rosa, Filipendula }\end{array}$ & & 7 & W \\
\hline RUBIACEAE & 3 & Galium & 3 & Galium & & & \\
\hline SALICACEAE & 4 & Salix & 5 & Salix, Populus & Salix & 4 & W \\
\hline SCROPHULARIACEAE & 5 & Digitalis, Veronica, Verbascum & 7 & Digitalis, Veronica, Verbascum & & 7 & W \\
\hline TILIACEAE & 3 & Tilia & 3 & Tilia & Tilia & 3 & W \\
\hline APIACEAE & 5 & $\begin{array}{c}\text { Foeniculum, Eryngium, Daucus, } \\
\text { Angelica }\end{array}$ & 6 & $\begin{array}{c}\text { Foeniculum, Eryngium, Daucus, } \\
\text { Angelica, Carum }\end{array}$ & & 5 & $\mathrm{~W}$ \\
\hline VIOLACEAE & 4 & Viola & 4 & Viola & & 3 & $\mathrm{~W}$ \\
\hline
\end{tabular}

Species belonging to the Lamiaceae (37 medicinal plant species), Orchidaceae (30), Rosaceae (26), and Asteraceae (16) plant families are the main species. Lamiaceae plant genera (e.g., Lavandula, Thymus, Teucrium, Salvia, Stachys) are visited by bees mainly as nectar sources, while Rosaceae (e.g., Malus, Prunus, Rubus, Crataegus) and Asteraceae (e.g., Aster, Taraxacum, Tussilago, Tanacetum, Helichrysum) are for both nectar and pollen foraging, although many plant species offer both nutrition resources to bees. On the opposite, genera of the Orchidaceae family (e.g., Anacamptis, Dactylorhiza, Ophris, Orchis) have a limited value for foraging, although these species attract wild bees (e.g., bumble bees of the genus Bombus) with their flowers [75]. Overall, many plants of these families have great relevance 
for oligolectic wild bees, which are adapted to collect pollen only from a small number of plant species [76].

By extending the analysis from the European medicinal plant checklist to some mainly cultivated or non-native medicinal plant species (Table 3), several plant taxa are of importance as sugar or pollen resources for bees.

Table 3. Some examples of plant taxon (family, genus) of cultivated/non-native medicinal plants in Europe, in relation to bee foraging sources (nectar, pollen). Plant data from Wichtl [77], bee preferences for pollen and nectar from MLR, [73], MAA, [74].

\begin{tabular}{cc}
\hline Plant Family & Nectar and Pollen Sources \\
\hline AMARYLLIDACEAE & Allium, Galanthus \\
BORAGINACEAE & Echium, Lithospermum, Anchusa \\
ASTERACEAE & Carlina, Centaurea, Helianthus, Calendula, Eupatorium, \\
CRUCIFERAE & Hieracium, Tanacetum, Artemisia, Bellis \\
CUCURBITACEAE & Iberis, Isatis, Erysimum \\
FABACEAE & Cucurbita, Bryonia \\
IRIDACEAE & Anthyllis, Lotus, Hedysarum, Cytisus \\
LAMIACEAE & Crocus, Iris \\
MYRTACEAE & Lavandula, Teucrium, Mentha, Satureja \\
ONAGRACEAE & Eucalyptus \\
PLANTAGINACEAE & Epilobium \\
RANUNCULACEAE & Linaria, Plantago \\
RHAMNACEAE & Helleborus, Nigella, Consolida \\
ROSACEAE & Rhamnus \\
RUTACEAE & Prunus, Geum \\
APIACEAE & Citrus \\
\end{tabular}

Some examples include tree species of the families Rutaceae (e.g., Citrus), Rosaceae (e.g., Prunus), Myrtaceae (e.g., Eucalyptus), shrubs of Fagaceae (e.g., Corylus), Eleagnaceae (e.g., Hippophae), and herbaceous species Asteraceae (e.g., Helianthus), Apiaceae (e.g., Coriandrum, Levisticum, Pimpinella), which are planted for different purposes (fruit crop, timber, vegetable) or belong to an anthropic habitat. An example of an interesting new medicinal and melliferous plant, the Perilla frutescens, an annual herb originating from China, Japan, India, Thailand and Korea, and belonging to the mint family (Lamiaceae) also grows in Italy, and is described and discussed by Barbieri and Ferrazzi [78].

In Figure 2, some medicinal plants growing in Italy are shown in relation to their foraging importance for bees (e.g., as sources of nectar, pollen, propolis or honeydew).

Apart from the nectar, bees also collect honeydew as a sugar source, if available in their foraging area. The main sources of honeydew are forests and conifer trees, which originate in the secretions from the living part of the plant (e.g., the leaves) or from sap-sucking insects [71]. In Europe, honeydew honey originates mainly from fir (Abies alba), spruce (Picea abies), and Pinus (e.g., Pinus halepensis, P. brutia) trees, but also from Salicaceae (Salix, Populus), Fagaceae (Castanea, Quercus), Oleaceae (Fraxinus, Olea), Tiliaceae (Tilia), Betulaceae (Betula) and Sapindaceae (Aesculus) [71]. Due to the variety of nectar and honeydew sources in natural or artificial habitats, a wide range of different types of honey can originate [79].

Various floral honeys are regarded as medicinal honeys with high polyphenol contents. Manuka dark-colored honey, for example, originates from Leptospermum scoparium and L. polygalifolium, shrubs native to Australia and New Zealand of the Myrtaceae family [80,81]. Another example are the honeys from Acacia ehrenbergina (Fabaceae) and Ziziphus spinachristi (Rhamnaceae), trees native to some areas of Africa and Asia, which show high phenolic contents [82]. Propolis originates from collected vegetable material by bees and is mixed with wax. Main sources for propolis production by bees are restricted to a small number of species, which are typical for specific geographic areas $[79,83]$. In Europe and North America, tree species of the genera Populus (e.g., Populus tremula, P. nigra in Europe, P. deltoides and P. trichocarpa in America) and Betula, are known as resin resources for 
bees, while in tropical and subtropical areas, Dalbergia and Acacia (Fabaceae), Macaranga (Euphorbiaceae), Mangifera and Rhus (Anacardiaceae), and Baccharis (Asteraceae), are the main sources. In the Mediterranean areas, where Populus species might be less frequent, the source of resins for propolis are the Cupressus sempervirens and the Juniperus phoenicea [84].
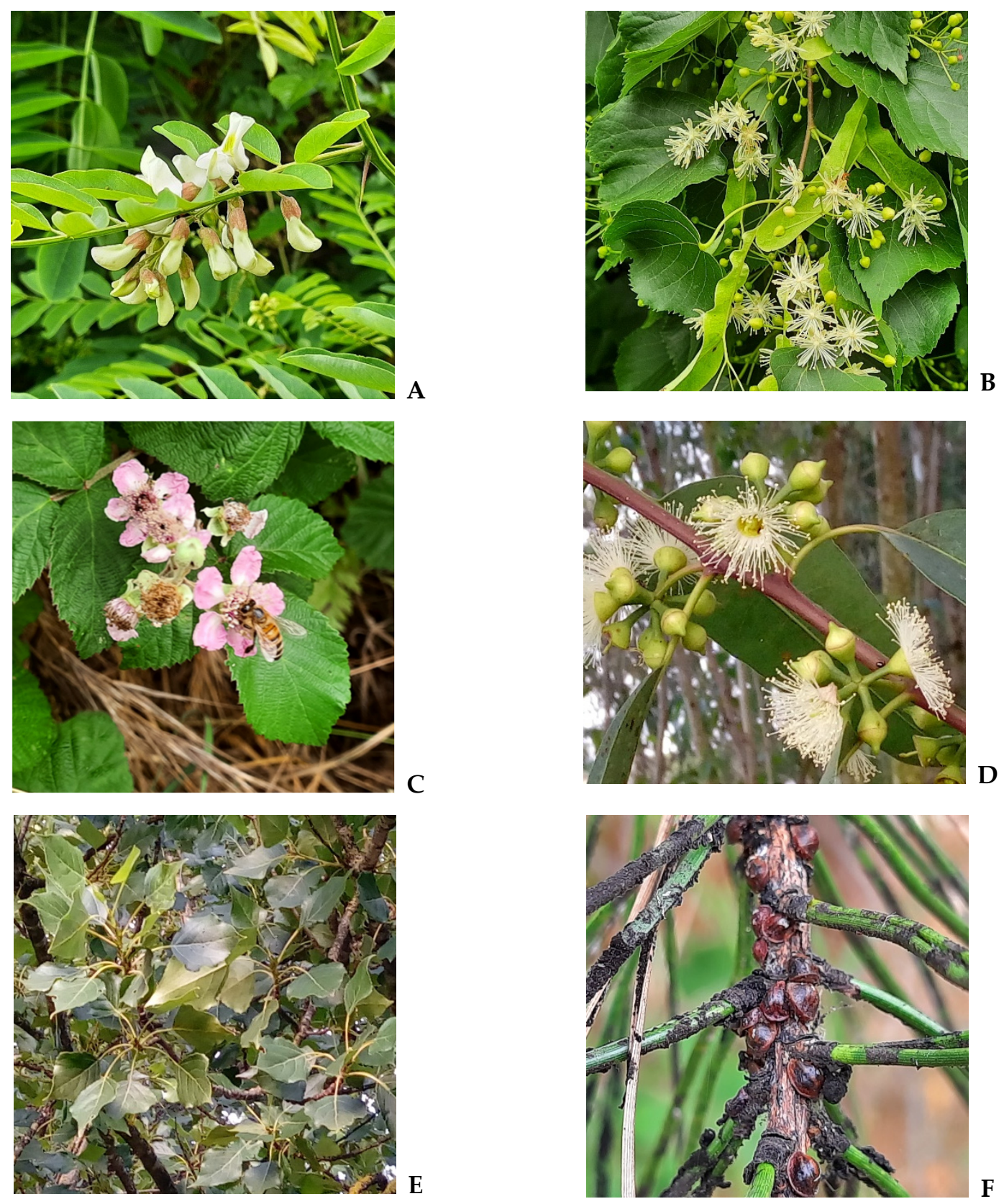

Figure 2. Examples of medicinal plant sources for bees: (A) Robinia pseudoacacia (nectar), (B) Tilia cordata (nectar, pollen, honeydew), (C) Rubus ulmifolius (nectar), (D) Eucalyptus camaldulensis (nectar, pollen, honeydew), (E) Populus nigra (propolis), (F) Pinus pinaster shoot heavily infested by Toumeyella parvicornis (pine tortoise scale, honeydew).

\section{Bee Products from Medicinal Plants: Antioxidant Properties Measurements}

Natural products, including bee products, which often contain medicinal plants containing compounds, such as honeydew secretions of Abies, Betula, Castanea, Fraxinus, Pinus, Quercus, Rosemary, Thymus, Tilia, and other species, are particularly appreciated by consumers for therapeutic uses as an alternative to drugs [85]. Antioxidants are sourced from the plant species. Medicinal plants generally recognized as having potential beneficial value can therefore be utilized to obtain honey with greater bioactivity and bioavailability. 
Nowadays, apitherapy has gained much attention from both consumers and researchers. In principle, apitherapy is a theory of alternative medicine that utilizes bee products, such as honey, pollen royal jelly, propolis, and bee venom, for medicinal purposes. However, it remains scarce and not exactly known whether treatments with bee products are safe and how the possible health risks of using such products can be minimized [85]. Proponents of apitherapy make claims for its health benefits, which in contrast, are unsupported by traditional medicine [50,86,87].

In this context, the antioxidant properties of bee products can be considered as an expression of the melliferous medicinal plants' therapeutic potential. Updates and considerations on the approach towards antioxidant properties have been mentioned; nonetheless, the conventional and innovative assays for the assessment of antioxidant properties and the remarkable antioxidant properties of bee products from medicinal plant cannot be neglected.

\subsection{Study Approach of the Antioxidant Properties: Updates and Considerations}

The combined action of bioactive compounds, nutrients, and nutraceuticals represents the first step to study antioxidant properties and can be regarded as an indicator of the "health properties" of the food matrices $[88,89]$.

The diversity of the chemical structure of compounds, their possible interactions, and their different mechanisms of action and biological role, make difficult the assessment of a single, adequate, and reliable procedure for the determination of antioxidant properties. Antioxidant properties are an expression of the interactions between bioactive molecules and other components in terms of both the potential health benefits of food and can be viewed as a screening method for interpretation and supporting further research. Extraction, antioxidant capacity measurements, and expression of the results can be viewed as the three key steps in the evaluation of the antioxidant properties. A study by Durazzo et al. [90] reported as the main workflow in research approach of the antioxidant properties three main steps, namely: (i) the development of a system as model study of the compounds' interactions; (ii) the investigation of extractable and non-extractable compounds; (iii) the behavior study of bioactive compounds-rich extracts.

Nowadays, the distinction between extractable and non-extractable antioxidants has been recognized as a fundamental aspect in the definition of the healthy properties in terms of the prevention of diseases [91,92]. In particular, the distinction between extractable and non-extractable antioxidants has achieved a shared consensus in the scientific community.

Indeed, new research directions point to the exploitation of new and unconventional sources for antioxidants and to the identification of new possible applications.

This research on the antioxidant properties should be based on an integrated and multidisciplinary approach, resulting from a combination of studies in several areas, such as nutrition, food chemistry, phytochemistry, and medicine. Innovative design of study research includes green procedures and sustainable technologies, and the joined up use of statistical methods, such as chemometrics.

An overall challenge is the development of dedicated databases for the antioxidant properties and the inclusion into harmonized databases; these are studies currently being carried out.

The inclusion of extractable and non-extractable compounds in current comprehensive and harmonized databases have been developed in the eBASIS BioActive Substances in Food Information System [93-95]. The development of search protocols and data collection systems have allowed to obtain new quality evaluated data on extractable and non-extractable antioxidants, used for the expansion eBASIS, leading thus, to a valuable unique data resource [96]. A total of 437 datapoints on the composition of extractable and/or non-extractable compounds were added into the database. This update of eBASIS can be viewed as the first examples of building a database dedicated to antioxidant properties. This eBASIS 'expansion provides a new and unique tool for dietitians, nutritionists, and researchers for a great range of uses, e.g., dietary assessment, epidemiological studies, and exposure studies [96]. 
In this context, the study of Pellegrini et al. [97], by summarizing 25 years of investigations on antioxidants research in foods and biological fluids, remarked how the availability of well-constructed Total Antioxidant Capacity databases deserves attention and must be considered. Moreover, the same authors highlighted how the appropriate use of Total Antioxidant Capacity measurement both in food and in vivo can still support interpretation of complex phenomena and can be viewed as a useful tool, for instance, for the sample screening when making a quick decision toward in-depth research investigations [97].

\subsection{Antioxidant Properties Assessment: An Overview of Conventional and Innovative Assays}

A variety of assays aimed at evaluating the dietary antioxidant properties have been proposed, although a reliable and commonly accepted assay has not been so far identified [98]. Overall, the methods available can be grouped into three major classes, namely in vitro, cellular, and in vivo assays. In vitro chemical assays are the most frequently used, because these are cheap and have high-throughput, but their prediction ability has been questioned in recent years [99,100]. Cell-based assays are considered a middle ground between the in vitro and in vivo tests (the latter posing ethical issues, high cost, and limited throughput) [101]. However, cellular antioxidant assays still suffer from poor standardization (e.g., differences in cell line, radical generators, fluorescent probes, etc.), making the reported results difficult to be compared across the available studies [102]. Moreover, some authors claimed that cell culturing itself may induce oxidative stress as a consequence of culture conditions, hence inducing cell acclimation and, thus, overestimating the antioxidants efficacy [103].

In this complex framework, in vitro tests still represent the most frequently used antioxidant assay methods in food science. Among others, they include the DPPH $(\alpha, \alpha-$ diphenyl- $\beta$-picrylhydrazyl), the ABTS (2,2'-azinobis(3-ethylbenzothiazolin-6-sulphonate), FRAP (ferric reducing antioxidant power), the CUPRAC (cupric-ion reducing antioxidant capacity), and ORAC (oxygen radical absorbance capacity) assays, [98,104-106]. The measurement of the ability of a food or a food component to scavenge specific free radicals or to reduce a target molecule are the base for all the above mentioned methods. Differences in their principles, mechanisms, experimental conditions, and in how their end points are measured occur, and for this reason the use of several methods to estimate and/or determine the antioxidant properties is suggested. Procedures and applications for these assays should be considered for standardization [107]. Moreover, one of the main concerns on the above mentioned assays is that these are not carried out under physiological conditions, and thus, their ability to predict in vivo effects has been questioned. Notwithstanding, most of the scientific literature on bee product antioxidant capacity is referred to in vitro tests, as with other foods, with the exception of a recent paper that investigated the cellular antioxidant capacity of different Moroccan Zantaz honey samples [108].

In general, in vitro assays account for different antioxidant mechanisms that include hydrogen atom transfer (HAT), and single electron transfer (SET) rather than chelation of transition metal ions. ORAC is probably the most representative HAT-based assay, while DPPH, CUPRAC, ABTS and FRAP are SET-based methods. However, the ability to chelate $\mathrm{Cu}^{2+}$ and $\mathrm{Fe}^{2+}$, a key initiation step in the oxidation processes, has also been considered in the context of the foods antioxidant properties [109].

Regarding the antioxidant properties of bee products, as with any other food, the limitations in these assays must be considered. Moreover, it must also be considered that in many situations, both HAT and SET occur simultaneously in vivo, and that antioxidant compounds may also act indirectly, via the regulation of antioxidant enzymes.

\subsection{Antioxidant Properties of Bee Products Relates to Foraging on Medicinal Plants}

The link between bee foraging on medicinal plants and antioxidant properties of bee products has received increasing attention. Nicewicz et al. [110] compared the antioxidant capacity of honey from urban areas vs. rural apiary, reporting that all antioxidant parameters were significantly higher in honey from rural than in urban areas. Such differences 
were not ascribed to the effect of the floral composition of honey, being rather due to the location of the honeybee colonies. In recent years, while wild pollinators are declining in many landscapes, urban areas provide high plant diversity and foraging sources for bees. Therefore, a growing interest for beekeeping in cities is observed, but the quality and safety of honey produced in urban areas impacts on the consumers' concerns. Therefore, further research in this direction is needed [75].

The following sub-sections discuss the relationship between floral diversity and bioactivity of bee products, with a specific focus on each product.

\subsubsection{Honey}

Honey (or honeybee honey) is a sugary foodstuff prepared by honeybees. Bees produce honey from the sugary secretions of plants (floral nectar) or from secretions of other insects of the Aphids family (honeydew) through their enzymatic activities and other biochemical processes, such as regurgitation and water evaporation. Honeybees store honey in wax structures called honeycombs, whereas stingless bees store honey in pots made of wax and resin [111]. Many centuries ago, in different civilizations, honey was used by ancient Greeks and Egyptians, and in Indian and Chinese traditional medicine both orally and topically to treat various illnesses. Traditional medicine reports uses towards stomach disorders, ulcers, skin wounds, and skin burns [112]. Several honey products have gained medical status and have been approved by the United States Food and Drug Administration (FDA) for their use in the treatment of wounds and burns [113]. It has been reported that honey has antioxidant, antibacterial, and antibiotic properties. The existence of numerous phytochemicals in different types of honey originating from plants known for their medicinal properties, such as Thymus, Abies, Pinus, Castanea, and Rosemary botanical species supports its antioxidant activity [114-118].

In more detail, Gheldof et al. [118] reported that buckwheat (Fagopyrum esculentum) honey increased human's serum antioxidant activity. Anand et al. [119] characterized the physico-chemical and antioxidant properties of Agastache honey produced from Agastache rugosa in comparison with commercial honeys sold in the Australia market. Their results confirmed that Agastache honey had a superior antioxidant capacity [119]. More recently, Adgaba et al. [120] studied, among others, the antioxidant and anti-microbial properties of some Ethiopian monofloral honeys, reporting average total antioxidant values of $320.3 \pm 15.1 \mu \mathrm{M}$ Fe(II) $/ 100 \mathrm{~g}$ with a range of $225.4-465.7 \mu \mathrm{M} \mathrm{Fe}(\mathrm{II}) / 100 \mathrm{~g}$. The same study reported relatively higher values $(421.5 \pm 23.4$ and $465.7 \pm 21.8 \mu \mathrm{M}$ Fe(II)/100 g) for Croton macrostachyus and Vernonia amygalina honeys, respectively. Nonetheless, in a review article focusing, among others, on the antioxidant properties of monofloral honeys, several honey types produced in different countries, such as acacia (Acacia sp.), astragalus (Astragalous microchephalus Willd), linden (Tilia sp.), willow (Salix sp.), and others, were reported to provide antioxidant capacity using multiple antioxidant assays, such as ABTS, DPPH, FRAP, ORAC, and TEAC (Trolox equivalent antioxidant capacity) [121].

The antioxidant activity of the studied honeys was affected by the botanical source and the geographical origin [121].

\subsubsection{Bee Pollen and Its Derivatives}

Bee pollen is among the honeybee products that contain nourishing nutrients, which can provide energy to humans. The health-enhancing value of bee pollen is owed to plant secondary metabolites, such as tocopherols, niacin, thiamine, biotin and folic acid, polyphenols, carotenoids, phytosterols, enzymes and other co-enzymes [85,122]. However, the studies highlighting the antioxidant, anti-inflammatory, anticariogenic antibacterial, antifungicidal, hepatoprotective, anti-atherosclerotic, immune enhancing properties need to be more extensive, concerning mainly the application of cohort clinical trials. The basic hurdle in the use of bee pollen as functional component is probably related to the broad species/specific variation in its composition [122]. Such variations may differently contribute to the properties of bee-pollen and biological activity, and thus, may affect 
its therapeutic effects (positively or negatively). Notwithstanding, bee pollen has been recommended as a valuable dietary supplement [85]. Pollen antioxidant activity has been related to a wide range of botanical species, such as Papaver rhoes, Chamomila recutita, Sinapis arvensis, Cistus sp., Trifolium sp., Dorycnium sp., Cichorium sp., Convolvulus sp., Circium sp., Malva sylvestris, Fumana sp., Eucalyptus camaldulensis, Anemone sp., Ononis sp., Asphodelus sp., and Quercus ilex [122].

Moving toward bee pollen-derived products, bee bread has a similar composition to bee pollen, but with marked quantitative differences mainly related to the fermentation process, which it undergoes. For instance, bee bread delivers higher amino acids, sugar, lactic acid, and vitamin content compared to bee pollen [123,124]. In a recent study, bee bread from different regions in Greece, containing Castanea sativa, Cistus sp., Hedera helix, Borago sp., and other pollen grains belonging to the Brassicaceae family, showed both antibacterial and antioxidant activity [125].

\subsubsection{Propolis}

Propolis, commonly known as the "bee glue" is a resinous mixture that honeybees produce by mixing their saliva, which contains enzymes and beeswax, with exudate gathered from different plant materials such as leaf and flower buds, stems, and bark cracks of numerous tree species. The word propolis originates from the two Greek words "pro" and "polis", which mean "defense" and "city" or "community," respectively [50]. Propolis is typically composed of $50-60 \%$ of resins and balms (including phenolic compounds), 30-40\% of wax and fatty acids, $5-10 \%$ of essential oils, $5 \%$ of pollen, and approximately $5 \%$ of other components, including amino acids, micronutrients, and vitamins (thiamin, riboflavin, pyridoxine, vitamins $\mathrm{C}$, and E). More than 300 compounds belonging to polyphenols, terpenoids, steroids, sugars, amino acids, and others have been identified in propolis [126].

The antioxidant activity of propolis has been determined by the use of in vitro methods, such as DPPH, ABTS+, FRAP, and ORAC [50]. Interestingly, the antioxidant activity of propolis extracts was comparable to the synthetic antioxidant butylated hydroxytoluene (BHT) or to ascorbic acid. Moreover, studies regarding the antioxidant properties of propolis, have also been carried out on cell cultures and animals. Clinical trials investigating the antioxidant effect of propolis reported a positive modulation of cardiovascular disease markers, a mitigation of chemotherapy side effects, as well as neuroprotective effects [127-129].

Similar to other bee products, plant sources are related to the profile of bioactive compounds and antioxidant properties of propolis [130,131]. More specifically, in regions with a large diversity of trees, bees may also gather resin from flowers in the genera Clusia (Clusia L.) and Dalechampia (Dalechampia L.), which are the major plant genera that produce floral resins to attract pollinators [132]. Clusia resin contains polyprenylated benzophenones $[133,134]$. In some areas of Chile and Brazil, propolis contains viscidone, a terpene from Baccharis (Baccharis L.) shrubs, and prenylated acids, such as 4-hydroxy-3,5diprenyl cinnamic acid $[135,136]$.

\subsubsection{Royal Jelly}

Royal jelly is a mixture of secretions from the mandibular and hypopharyngeal glands of bees of the Apis mellifera species, representing the major food source for the queen honeybee [50]. Concerning its composition, royal jelly is an emulsion of proteins, sugars, and lipids in water. Moreover, it contains approximately $1.5 \%(w / w)$ of minerals (mainly copper, zinc, iron, calcium, manganese, potassium, and sodium) and considerable amounts of flavonoids, polyphenols, and vitamins (biotin, folic acid, inositol, niacin, pantothenic acid, riboflavin, thiamine, and vitamin E). Among the flavonoids, the flavanones (hesperetin, isosakuranetin, and naringenin), flavones (acacetin, apigenin, and its glucoside, chrysin, and luteolin glucoside), flavonols (isorhamnetin and kaempferol glucosides), and isoflavonoids (coumestrol, formononetin, and genistein) are the most abundant [137]. 
The antioxidant activity of royal jelly, in terms of DPPH, hydroxyl and superoxide radical scavenging, has been reported in the literature $[138,139]$. In this regard, both in vitro and in vivo tests have been conducted, whereas less information has been reported from clinical trials. In a recent study carried out by Pourmoradian et al. [140], the positive impact of royal jelly consumption on the parameters associated with diabetes and oxidative stress in people affected by Type 2 diabetes mellitus has been postulated. On the other hand, studies on rats and rabbits reported that royal jelly intake can be associated with antioxidant and neuroprotective effects $[141,142]$. This is consistent with the antioxidant activity of monophosphate nucleotides and peptides isolated from royal jelly [143].

More generally, the antioxidant activity of royal jelly may be differentiated compared to honey, bee pollen and propolis. However, the specific contribution of the botanical species available for foraging on the actual functional properties of royal jelly is still poor.

\section{Conclusions and Future Directions}

It is clear that medicinal plants can contribute to the antioxidant activity of bee products along with the honeybee contribution as a living organism; the antioxidant properties can be regarded as an indicator of the melliferous medicinal plant's potential. In this context, more research should be focused on bee products obtained from the broad range of medicinal plants and on the identification of the possible relationships between the bioactive components, which are present in plant parts and their nectars as well as the bee products.

At the same time, research and clinical trials should be conducted on humans to assess the relationship between the consumption of bee products and the aiding or treatment in health disorders. In this way, the potential use of bee products in phytomedicine (as an alternative to drugs) could be better substantiated by the scientific evidence. The complementary use of the nanotechnologies $[144,145]$ opens new directions and new frontiers. For instance, Neupane et al. [146], by developing Himalayan honey-loaded iron oxide nanoparticles, showed that the biological activity of Himalayan honey was enhanced significantly after loading into iron oxide nanoparticles. Sarhan and Azzazy [147] developed biocompatible, antimicrobial crosslinked honey/polyvinyl alcohol/chitosan nanofibers, which hold potential as an effective wound dressing source. These aspects are relevant and trigger an additional interest for research to obtain a greater bioavailability and efficacy of bee products in the field of health, including anti-COVID-19 possible beneficial effects [148-151], also increasing the interest in studies that are carried out to assess the safety aspects of nanoformulations, which are indeed new frontiers to explore.

Author Contributions: All authors have made a substantial contribution to the writing and revision of work, and approved it for publication. All authors have read and agreed to the published version of the manuscript.

Funding: This research received no external funding.

Institutional Review Board Statement: Not applicable.

Informed Consent Statement: Not applicable.

Conflicts of Interest: The authors declare no conflict of interest.

\section{References}

1. Martinello, M.; Mutinelli, F. Antioxidant activity in bee products: A review. Antioxidants 2021, 10, 71. [CrossRef] [PubMed]

2. Birben, E.; Sahiner, U.M.; Sackesen, C.; Erzurum, S.; Kalayci, O. Oxidative stress and antioxidant defense. World Allergy Organ. J. 2012, 5, 9-19. [CrossRef]

3. Halliwell, B.; Gutteridge, J.M.C. Free Radicals in Biology and Medicine, 3rd ed.; Oxford University Press: New York, NY, USA, 1999.

4. Valko, M.; Leibfritz, D.; Moncol, J.; Cronin, M.T.D.; Mazur, M.; Telser, J. Free radicals and antioxidants in normal physiological functions and human disease. Int. J. Biochem. Cell Biol. 2007, 39, 44-84. [CrossRef]

5. Halliwell, B. Biochemistry of oxidative stress. Biochem. Soc. Trans. 2007, 35, 1147-1150. [CrossRef] [PubMed]

6. Genestra, M. Oxyl radicals, redox-sensitive signalling cascades and antioxidants. Cell. Signal. 2007, 19, 1807-1819. [CrossRef] 
7. Pizzino, G.; Irrera, N.; Cucinotta, M.; Pallio, G.; Mannino, F.; Arcoraci, V.; Squadrito, F.; Altavilla, D.; Bitto, A. Oxidative Stress: Harms and Benefits for Human Health. Oxid. Med. Cell. Longev. 2017, 2017, 8416763. [CrossRef]

8. Uttara, B.; Singh, A.V.; Zamboni, P.; Mahajan, R.T. Oxidative Stress and Neurodegenerative Diseases: A Review of Upstream and Downstream Antioxidant Therapeutic Options. Curr. Neuropharmacol. 2009, 7, 65-74. [CrossRef]

9. Hayes, J.D.; Dinkova-Kostova, A.T.; Tew, K.D. Oxidative stress in cancer. Cancer Cell 2020, 38, 167-197. [CrossRef]

10. Huang, D.; Ou, B.; Prior, R.L. The Chemistry behind Antioxidant Capacity Assays. J. Agric. Food Chem. 2005, 53, 1841-1856. [CrossRef] [PubMed]

11. Alvarez-Suarez, J.; Giampieri, F.; Battino, M. Honey as a Source of Dietary Antioxidants: Structures, Bioavailability and Evidence of Protective Effects Against Human Chronic Diseases. Curr. Med. Chem. 2013, 20, 621-638. [CrossRef]

12. Durazzo, A.; Lucarini, M.; Cicero, N.; Gabrielli, P.; Souto, E.B.; Dugo, G.; Santini, A. The Antioxidant Properties of Honey. In Search of Honey Authentication; Karabagias, I., Ed.; Cambridge Scholars Publishing: Newcastle upon Tyne, UK, 2021; ISBN (10): 1-5275-6712-5, ISBN (13): 978-1-5275-6712-2.

13. Waltman, L.; van Eck, N.J.; Noyons, E.C.M. A unified approach to mapping and clustering of bibliometric networks. J. Inf. 2010, 4, 629-635. [CrossRef]

14. Van Eck, N.J.; Waltman, L. Software survey: VOSviewer, a computer program for bibliometric mapping. Scientometrics 2009, 84, 523-538. [CrossRef] [PubMed]

15. Van Eck, N.J.; Waltman, L. Text mining and visualization using VOSviewer. ISSI Newslett. 2011, 7, 50-54.

16. Khalifa, S.A.M.; Elshafiey, E.H.; Shetaia, A.A.; El-Wahed, A.A.A.; Algethami, A.F.; Musharraf, S.G.; AlAjmi, M.F.; Zhao, C.; Masry, S.H.D.; Abdel-Daim, M.M.; et al. Overview of Bee Pollination and Its Economic Value for Crop Production. Insects 2021, 12, 688. [CrossRef]

17. Robinson ACPeeler, J.L.; Prestby, T.; Goslee, S.C.; Anton, K.; Grozinger, C. Beescape: Characterizing user needs for environmental decision support in beekeeping. Ecol. Inform. 2021, 64, 101366. [CrossRef]

18. Delaplane, K.S.; Mayer, D.F. Crop Pollination by Bees; CABI: Wallingford, UK, 2000.

19. Dogantzis, K.A.; Zayed, A. Recent advances in population and quantitative genomics of honey bees. Curr. Opin. Insect Sci. 2019, 31, 93-98. [CrossRef]

20. Klein, A.-M.; Vaissière, B.E.; Cane, J.H.; Steffan-Dewenter, I.; Cunningham, S.A.; Kremen, C.; Tscharntke, T. Importance of pollinators in changing landscapes for world crops. Proc. R. Soc. B Biol. Sci. 2007, 274, 303-313. [CrossRef]

21. Bloch, G.; Francoy, T.M.; Wachtel, I.; Panitz-Cohen, N.; Fuchs, S.; Mazar, A. Industrial apiculture in the Jordan valley during Biblical times with Anatolian honeybees. Proc. Natl. Acad. Sci. USA 2010, 107, 11240-11244. [CrossRef]

22. Crane, E. Honeybees. In Evolution of Domesticated Animals; Mason, I.L., Ed.; Longman Group: London, UK, $1984 ;$ pp. $403-415$.

23. Phillips, E.F. Beekeeping; Applewood Books: Carlisle, MA, USA, 1918.

24. Bruckner, S.; Steinhauer, N.; Engelsma, J.; Fauvel, A.M.; Kulhanek, K.; Malcom, E.; Meredith, A.; Milbrath, M.; Nino, E.; Rangel, J.; et al. 2019-2020 Honey Bee Colony Losses in the United States: Preliminary Results. 2020, p. 5. Available online: https:/ / beeinformed.org/wp-content/uploads/2020/06/BIP_2019_2020_Losses_Abstract.pdf (accessed on 28 October 2021).

25. Potts, S.G.; Biesmeijer, J.C.; Kremen, C.; Neumann, P.; Schweiger, O.; Kunin, W.E. Global pollinator declines: Trends, impacts and drivers. Trends Ecol. Evol. 2010, 25, 345-353. [CrossRef]

26. Tautz, J. The Buzz about Bees: Biology of a Superorganism; Springer: Berlin/Heidelberg, Germany, 2008.

27. Ascher, J.S.; Pickering, J. Discover Life Bee Species Guide and World Checklist (Hymenoptera: Apoidea: Anthophila). 2014. Available online: http:/ / www.discoverlife.org/mp/20q?guide=Apoidea_species (accessed on 28 October 2021).

28. Themudo, G.E.; Rey-Iglesia, A.; Tascón, L.R.; Jensen, A.B.; Da Fonseca, R.R.; Campos, P.F. Declining genetic diversity of European honeybees along the twentieth century. Sci. Rep. 2020, 10, 1-12. [CrossRef]

29. Potts, S.G.; Roberts, S.P.; Dean, R.; Marris, G.; Brown, M.A.; Jones, R.; Neumann, P.; Settele, J. Declines of managed honey bees and beekeepers in Europe. J. Apic. Res. 2010, 49, 15-22. [CrossRef]

30. Berkes, F.; Colding, J.; Folke, C. Navigating Social-Ecological Systems: Building Resilience for Complexity; Cambridge University Press: Cambridge, UK, 2003; pp. 1-30.

31. Keune, H.; Dendoncker, N.; Jacobs, S. Ecosystem Service Practices. In Ecosystem Services; Elsevier: Amsterdam, The Netherlands, 2013; pp. 307-315.

32. Martinello, M.; Manzinello, C.; Dainese, N.; Giuliato, I.; Gallina, A.; Mutinelli, F. The Honey Bee: An Active Biosampler of Environmental Pollution and a Possible Warning Biomarker for Human Health. Appl. Sci. 2021, 11, 6481. [CrossRef]

33. Adeoye, O.T.; Pitan, O.R.; Olasupo, O.O.; Ayandokun, A.E.; Abudul-Azeez, F.I. Assessment of honeybees and bee honey as bioindicators of environmental pollution. Aust. J. Sci. Technol. 2021, 5, 460-465.

34. Horcea-Milcu, A.-I.; Hanspach, J.; Abson, D.; Fischer, J. Cultural Ecosystem Services: A Literature Review and Prospects for Future Research. Ecol. Soc. 2013, 18, 44. [CrossRef]

35. Bennett, E.M.; Peterson, G.; Gordon, L. Understanding relationships among multiple ecosystem services. Ecol. Lett. 2009, 12, 1394-1404. [CrossRef]

36. FAO. Bees and their role in forest livelihoods. In A Guide to the Services Provided by Bees and the Sustainable Harvesting Processing and Marketing of Their Products; FAO: Rome, Italy, 2009.

37. Michener, C.D. The Bees of the World; The John Hopkins University Press: Baltimore, MD, USA, $2000 ;$ p. 913.

38. Michener, C.D. The Bees of the World, 2nd ed.; John Hopkins University Press: Baltimore, MD, USA, 2007. 
39. Chinwuba Okoye, T.; Uzor, P.F.; Onyeto, C.A.; Okereke, E.K. Chapter 18-Safe African medicinal plants for clinical studies. In Toxicological Survey of African Medicinal Plants; Elsevier: Amsterdam, The Netherlands, 2014; pp. 535-555.

40. Asadi, N.; Bahmani, M.; Shahsavari, S.; Asadi-Samani, M. Identification and introduction of the medicinal plants used by Honeybees in Markazi Province. IJPPR 2017, 7, 15-18.

41. Bahmani, M.; Asadi-Samani, M. Native medicinal plants of Iran effective on peptic ulcer. J. Injury Inflam. 2016,1 , e05.

42. Moradi, M.T.; Asadi-Samani, M.; Bahmani, M.; Shahrani, M. Medicinal plants used for liver disorders based on the ethnobotanical documents of Iran: A review. Int. J. PharmTech Res. 2016, 9, 407-415.

43. Molan, P. Why honey is effective as a medicine: 2. The scientific explanation of its effects. Bee World 2001, 82, 22-40. [CrossRef]

44. Verma, L.R. Beekeeping. In Integrated Mountain Development: Economic and Scientific Perspectives; International Centre for Integrated Mountain Development (ICIMOD): Patan, Nepal, 1990.

45. Kaur, G.; Sihag, R.C. Bee flora of India: A review. Bee J. 1994, 56, 105-126.

46. Partap, U. Bee Flora of the Hindu Kush-Himalayas: Inventory and Management; ICMOD: Kathmandu, Nepal, 1997.

47. Harugade, S.; Gawate, A.; Shinde, B. Bee Floral Diversity of Medicinal Plants in Vidya Pratishthan Campus, Baramati, Pune, District (M.S.) India. Int. J. Curr. Microbiol. Appl. Sci. 2016, 5, 425-431. [CrossRef]

48. Mačukanović-Jocić, M.; Jarić, S.V. The melliferous potential of apiflora of southwestern Vojvodina (Serbia). Arch. Biol. Sci. 2016, 68, 81-91. [CrossRef]

49. Bakour, M.; Laaroussi, H.; El Menyiy, N.; Elaraj, T.; El Ghouizi, A.; Lyoussi, B. The Beekeeping State and Inventory of MelliferoMedicinal Plants in the North-Central of Morocco. Sci. World J. 2021, 2021, 1-12. [CrossRef]

50. Kocot, J.; Kiełczykowska, M.; Luchowska-Kocot, D.; Kurzepa, J.; Musik, I. Antioxidant Potential of Propolis, Bee Pollen, and Royal Jelly: Possible Medical Application. Oxid. Med. Cell. Longev. 2018, 2018, 1-29. [CrossRef]

51. Feás, X.; Vázquez-Tato, M.P.; Estevinho, L.; Seijas, J.A.; Iglesias, A. Organic bee pollen: Botanical origin, nutritional value, bioactive compounds, antioxidant activity and microbiological quality. Molecules 2012, 17, 8359-8377. [CrossRef]

52. Paulino, N.; Coutinho, L.A.; Coutinho, J.R.; Vilela, G.C.; da Silva Leandro, V.P.; Paulino, A.S. Antiulcerogenic effect of Brazilian propolis formulation in mice. Pharmacol. Pharm. 2015, 6, 580. [CrossRef]

53. Kaplan, M.; Karaoglu, O.; Eroglu, N.; Silici, S. Fatty Acid and proximate composition of bee bread. Food Technol. Biotechnol. 2016, 54, 497-504. [CrossRef]

54. Shaddel-Telli, A.; Maheri, N.; Aghajanzade, G. Using medicinal plants for controlling Varrova Mite honeybee colonies. J. Anim. Vet. Adv. 2008, 7, 328-330.

55. Bendifallah, L.; Belguendouz, R.; Hamoudi, L.; Arab, K. Biological Activity of the Salvia officinalis L. (Lamiaceae) Essential Oil on Varroa destructor Infested Honeybees. Plants 2018, 7, 44. [CrossRef]

56. Topal, E.; Cıpcıgan, M.; İvgin Tunca, R.; Kösoğlu, M.; Mărgăoan, R. The Use of medicinal aromatic plants against bee diseases and pests. Bee Stud. 2020, 12, 5-11. [CrossRef]

57. Khan, S.U.; Anjum, S.I.; Ansari, M.J.; Khan, M.H.U.; Kamal, S.; Rahman, K.; Shoaib, M.; Man, S.; Khan, A.J.; Khan, S.U.; et al Antimicrobial potentials of medicinal plant's extract and their derived silver nanoparticles: A focus on honey bee pathogen. Saudi J. Biol. Sci. 2019, 26, 1815-1834. [CrossRef] [PubMed]

58. Nguyen, H.T.L.; Panyoyai, N.; Paramita, V.D.; Mantri, N.; Kasapis, S. Physicochemical and viscoelastic properties of honey from medicinal plants. Food Chem. 2018, 241, 143-149. [CrossRef] [PubMed]

59. Durazzo, A.; D'Addezio, L.; Camilli, E.; Piccinelli, R.; Turrini, A.; Marletta, L.; Marconi, S.; Lucarini, M.; Lisciani, S.; Gabrielli, P.; et al. From Plant Compounds to Botanicals and Back: A Current Snapshot. Molecules 2018, 23, 1844. [CrossRef]

60. Durazzo, A.; Lucarini, M.; Souto, E.B.; Cicala, C.; Caiazzo, E.; Izzo, A.A.; Novellino, E.; Santini, A. Polyphenols: A concise overview on the chemistry, occurrence, and human health. Phytother. Res. 2019, 33, 2221-2243. [CrossRef]

61. Durazzo, A.; Lucarini, M. Editorial: The State of Science and Innovation of Bioactive Research and Applications, Health, and Diseases. Front. Nutr. 2019, 6, 178. [CrossRef] [PubMed]

62. Durazzo, A.; Camilli, E.; D’Addezio, L.; Piccinelli, R.; Mantur-Vierendeel, A.; Marletta, L.; Finglas, P.; Turrini, A.; Sette, S. Development of Dietary Supplement Label Database in Italy: Focus of FoodEx2 Coding. Nutrients 2019, 12, 89. [CrossRef]

63. Daliu, P.; Santini, A.; Novellino, E. A decade of nutraceutical patents: Where are we now in 2018? Expert Opin. Ther. Pat. 2018, 28, 875-882. [CrossRef]

64. Santini, A.; Cammarata, S.M.; Capone, G.; Ianaro, A.; Tenore, G.C.; Pani, L.; Novellino, E. Nutraceuticals: Opening the debate for a regulatory framework. Br. J. Clin. Pharmacol. 2018, 84, 659-672. [CrossRef] [PubMed]

65. Lange, D. Europe's Medicinal and Aromatic Plants: Their Use, Trade and Conservation; Traffic International: Cambridge, UK, 1998.

66. Diazgranados, M.; Allkin, B.; Black, N.; Cámara-Leret, R.; Canteiro, C.; Carretero, J.; Ulian, T. World Checklist of Useful Plant Species. Produced by the Royal Botanic Gardens, Kew. Knowledge Network for Biocomplexity. 2020. Available online: https:/ / kew.iro.bl.uk/concern/datasets/7243d727-e28d-419d-a8f7-9ebef5b9e03e?locale=en (accessed on 28 October 2021).

67. Dürbeck, K.; Hüttenhofer, T. International Trade of Medicinal and Aromatic Plants. Med. Aromat. Plants World 2015, 1, 375-382. [CrossRef]

68. Allen, D.; Bilz, M.; Leaman, D.J.; Miller, R.M.; Timoshyna, A.; Window, J. European Red List of medicinal Plants; Publications Office of the European Union: Luxembourg, 2014; p. 63.

69. Bankova, V.; Popova, M.; Trusheva, B. The phytochemistry of the honeybee. Phytochemistry 2018, 155, 1-11. [CrossRef] 
70. Bogdanov, S.; Ruoff, K.; Oddo, L.P. Physico-chemical methods for the characterisation of unifloral honeys: A review. Apidologie 2004, 35 (Suppl. 1), S4-S17. [CrossRef]

71. Pita-Calvo, C.; Vázquez, M. Honeydew Honeys: A Review on the Characterization and Authentication of Botanical and Geographical Origins. J. Agric. Food Chem. 2018, 66, 2523-2537. [CrossRef] [PubMed]

72. Thakur, M.; Nanda, V. Composition and functionality of bee pollen: A review. Trends Food Sci. Technol. 2020, 98, 82-106. [CrossRef]

73. MLR-Ministerium für ländlichen Raum und Verbraucherschutz Baden-Württemberg. Bienenweidekatalog: Verbesserung der Bienenweide und des Artenreichtums.-Stuttgart. 129 S. 2018. Available online: https://mlr.baden-wuerttemberg.de/de/unserethemen/biodiversitaet-und-landnutzung/bienenweidekatalog/ (accessed on 28 October 2021).

74. MAA-Ministère de l'Agriculture et de l'Alimentation. Liste de plantes attractives pour les abeilles. 2017. Available online: https:/ / www.franceagrimer.fr/content/download/51417/494444/file/290517-Plantes\%20attractives-abeilles.pdf (accessed on 28 October 2021).

75. Vöth, W. Lebensgeschichte und Bestäuber der Orchideen am Beispiel von Niederösterreich. Biologiezentrum des OÖ; Landesmuseums: Zürich, Switzerland, 1999; Volume 65, Biologiezentrum Linz/Austria.

76. Kratochwil, A. Bees (Hymenoptera: Apoidea) as key-stone species: Specifics of resource and requisite utilisation in different habitat types. Ber. Der Reinhold-Tüxen-Ges. 2003, 15, 59-77.

77. Wichtl, M. Teedrogen und Phytopharmaka; Wissenschaftiche Verlag GmbH: Stuttgart, Germany, 2002; Volume 4, p. 84.

78. Barbieri, C.; Ferrazzi, P. Perilla frutescens: Interesting New Medicinal and Melliferous Plant in Italy. Nat. Prod. Commun. 2011, 6, 1461-1463. [CrossRef]

79. Oddo, L.P.; Piro, R.; Bruneau, É.; Guyot-Declerck, C.; Ivanov, T.; Piskulová, J.; Flamini, C.; Lheritier, J.; Morlot, M.; Russmann, H.; et al. Main European unifloral honeys: Descriptive sheets. Apidologie 2004, 35 (Suppl. 1), S38-S81. [CrossRef]

80. Stephens, J.M.; Schlothauer, R.C.; Morris, B.D.; Yang, D.; Fearnley, L.; Greenwood, D.R.; Loomes, K.M. Phenolic compounds and methylglyoxal in some New Zealand manuka and kanuka honeys. Food Chem. 2010, 120, 78-86. [CrossRef]

81. Alzahrani, H.A.; Boukraa, L.; Bellik, Y.; Abdellah, F.; Bakhotmah, B.A.; Kolayli, S.; Sahin, H. Evaluation of the Antioxidant Activity of Three Varieties of Honey from Different Botanical and Geographical Origins. Glob. J. Health Sci. 2012, 4, 191-196. [CrossRef]

82. Al-Mamary, M.; Al-Meeri, A.; Al-Habori, M. Antioxidant activities and total phenolics of different types of honey. Nutr. Res. 2002, 22, 1041-1047. [CrossRef]

83. Bankova, V.; Popova, M.; Trusheva, B. Plant sources of propolis: An update from a chemist's point of view. Nat. Prod. Commun. 2006, 1. [CrossRef]

84. Velikova, M.; Bankova, V.; Sorkun, K.; Houcine, S.; Tsvetkova, I.; Kujumgiev, A. Propolis from the Mediterranean Region: Chemical Composition and Antimicrobial Activity. Z. Naturforschung C 2000, 55, 790-793. [CrossRef]

85. Denisow, B.; Denisow-Pietrzyk, M. Biological and therapeutic properties of bee pollen: A review. J. Sci. Food Agric. 2016, 96, 4303-4309. [CrossRef] [PubMed]

86. Russell, J.; Rovere, A. Apitherapy. In American Cancer Society Complete Guide to Complementary and Alternative Cancer Therapies, 2nd ed.; American Cancer Society: Atlanta, GA, USA, 2009; pp. 704-708.

87. Cassileth, B.R. Apitherapy. In The Complete Guide to Complementary Therapies in Cancer Care: Essential Information for Patients, Survivors and Health Professionals; World Scientific: Singapore, 2011; pp. 221-224.

88. Durazzo, A. Study Approach of Antioxidant Properties in Foods: Update and Considerations. Foods 2017, 6, 17. [CrossRef]

89. Durazzo, A.; Lucarini, M.; Santini, A. Nutraceuticals in Human Health. Foods 2020, 9, 370. [CrossRef] [PubMed]

90. Durazzo, A.; Lucarini, M. A Current Shot and Re-thinking of Antioxidant Research Strategy. Braz. J. Anal. Chem. 2019, 5, 9-11. [CrossRef]

91. Durazzo, A.; Lucarini, M. Extractable and non-extractable antioxidants. Molecules 2019, 24, 1933. [CrossRef]

92. Durazzo, A. Extractable and non-extractable polyphenols: An overview. In Non-Extractable Polyphenols and Carotenoids: Importance in Human Nutrition and Health; Saura-Calixto, F., Pérez-Jiménez, J., Eds.; RSC Publishing: Cambridge, UK, 2018 ; pp. 37-45. ISBN 978-1-78801-447-2. [CrossRef]

93. eBASIS-Bioactive Substances in Food Information System. Available online: http:/ / ebasis.eurofir.org/Default.asp (accessed on 4 June 2021).

94. Kiely, M.; on behalf of the EuroFIR consortium; Black, L.J.; Plumb, J.; Kroon, P.A.; Hollman, P.C.; Larsen, J.C.; Speijers, G.J.; Kapsokefalou, M.; Sheehan, D.; et al. EuroFIR eBASIS: Application for health claims submissions and evaluations. Eur. J. Clin. Nutr. 2010, 64, S101-S107. [CrossRef]

95. Plumb, J.; Pigat, S.; Bompola, F.; Cushen, M.; Pinchen, H.; Nørby, E.; Astley, S.; Lyons, J.; Kiely, M.; Finglas, P. eBASIS (Bioactive Substances in Food Information Systems) and bioactive intakes: Major updates of the bioactive compound composition and beneficial bio effects database and the development of a probabilistic model to assess intakes in Europe. Nutrients 2017, 9, 320. [CrossRef]

96. Plumb, J.; Durazzo, A.; Lucarini, M.; Camilli, E.; Turrini, A.; Marletta, L.; Finglas, P. Extractable and Non-Extractable Antioxidants Composition in the eBASIS Database: A Key Tool for Dietary Assessment in Human Health and Disease Research. Nutrients 2020, 12, 3405. [CrossRef] [PubMed]

97. Pellegrini, N.; Vitaglione, P.; Granato, D.; Fogliano, V. Twenty-five years of total antioxidant capacity measurement of foods and biological fluids: Merits and limitations. J. Sci. Food Agric. 2020, 100, 5064-5078. [CrossRef] 
98. Apak, R. Current Issues in Antioxidant Measurement. J. Agric. Food Chem. 2019, 67, 9187-9202. [CrossRef] [PubMed]

99. Cömert, E.D.; Gökmen, V. Evolution of food antioxidants as a core topic of food science for a century. Food Res. Int. 2018, 105, 76-93. [CrossRef]

100. Granato, D.; Shahidi, F.; Wrolstad, R.; Kilmartin, P.; Melton, L.D.; Hidalgo, F.J.; Miyashita, K.; van Camp, J.; Alasalvar, C.; Ismail, A.; et al. Antioxidant activity, total phenolics and flavonoids contents: Should we ban in vitro screening methods? Food Chem. 2018, 264, 471-475. [CrossRef]

101. Martinelli, E.; Granato, D.; Azevedo, L.; Gonçalves, J.E.; Lorenzo, J.M.; Munekata, P.E.; Simal-Gandara, J.; Barba, F.J.; Carrillo, C.; Rajoka, M.S.R.; et al. Current perspectives in cell-based approaches towards the definition of the antioxidant activity in food. Trends Food Sci. Technol. 2021, 116, 232-243. [CrossRef]

102. Kellett, M.E.; Greenspan, P.; Pegg, R.B. Modification of the cellular antioxidant activity (CAA) assay to study phenolic antioxidants in a Caco-2 cell line. Food Chem. 2018, 244, 359-363. [CrossRef] [PubMed]

103. Amorati, R.; Valgimigli, L. Advantages and limitations of common testing methods for antioxidants. Free Radic. Res. 2015, 49, 633-649. [CrossRef] [PubMed]

104. Apak, R.; Özyürek, M.; Güçlü, K.; Çapanoğlu, E. Antioxidant Activity/Capacity Measurement. 1. Classification, Physicochemical Principles, Mechanisms, and Electron Transfer (ET)-Based Assays. J. Agric. Food Chem. 2016, 64, 997-1027. [CrossRef]

105. Apak, R.; Özyürek, M.; Güçlü, K.; Çapanoğlu, E. Antioxidant Activity/Capacity Measurement. 2. Hydrogen Atom Transfer (HAT)-Based, Mixed-Mode (Electron Transfer (ET)/HAT), and Lipid Peroxidation Assays. J. Agric. Food Chem. 2016, 64, 1028-1045. [CrossRef]

106. Apak, A.; Capanoglu, E.; Shahidi, F. Measurement of Antioxidant Activity and Capacity: Recent Trends and Applications; Wiley: New York, NY, USA, 2018; ISBN 978-1-119-13535-7.

107. Prior, R.L.; Wu, X.; Schaich, K. Standardized Methods for the Determination of Antioxidant Capacity and Phenolics in Foods and Dietary Supplements. J. Agric. Food Chem. 2005, 53, 4290-4302. [CrossRef]

108. Elamine, Y.; Lyoussi, B.; Miguel, M.G.; Anjos, O.; Estevinho, L.; Alaiz, M.; Girón-Calle, J.; Martín, J.; Vioque, J. Physicochemical characteristics and antiproliferative and antioxidant activities of Moroccan Zantaz honey rich in methyl syringate. Food Chem. 2021, 339, 128098. [CrossRef]

109. Santos, J.S.; Deolindo, C.T.P.; Hoffmann, J.F.; Chaves, F.C.; Prado-Silva, L.D.; Sant'Ana, A.S.; Azevedo, L.; Carmo, M.A.V.D.; Granato, D. Optimized Camellia sinensis var. sinensis, Ilex paraguariensis, and Aspalathus linearis blend presents high antioxidant and antiproliferative activities in a beverage model. Food Chem. 2018, 254, 348-358. [CrossRef] [PubMed]

110. Nicewicz, A.W.; Nicewicz, Ł.; Pawłowska, P. Antioxidant capacity of honey from the urban apiary: A comparison with honey from the rural apiary. Sci. Rep. 2021, 11, 1-8. [CrossRef]

111. Crane, E. Honey from honeybees and other insects. Ethol. Ecol. Evol. 1991, 3, 100-105. [CrossRef]

112. Pećanac, M.; Janjić, Z.; Komarcević, A.; Pajić, M.; Dobanovacki, D.; Misković, S.S. Burns treatment in ancient times. Med. Pregl. 2013, 66, 263-267. [PubMed]

113. Saikaly, S.K.; Khachemoune, A. Honey and Wound Healing: An Update. Am. J. Clin. Dermatol. 2017, 18, 237-251. [CrossRef] [PubMed]

114. Majtan, J.; Klaudiny, J.; Bohova, J.; Kohutova, L.; Dzurova, M.; Sediva, M.; Bartosova, M.; Majtan, V. Methylglyoxal-induced modifications of significant honeybee proteinous components in manuka honey: Possible therapeutic implications. Fitoterapia 2012, 83, 671-677. [CrossRef]

115. Kwakman, P.H.S.; Zaat, S.A.J. Antibacterial components of honey. IUBMB Life 2012, 64, 48-55. [CrossRef]

116. Karabagias, I.K.; Dimitriou, E.; Kontakos, S.; Kontominas, M.G. Phenolic profile, colour intensity, and radical scavenging activity of Greek unifloral honeys. Eur. Food Res. Technol. 2016, 242, 1201-1210. [CrossRef]

117. Koca, I.; Tekguler, B.; Turkyilmaz, B.; Tasci, B. Some physical, chemical and antioxidant properties of chestnut (Castanea sativa Mill.) honey produced in Turkey. Acta Hortic. 2018, 1220, 227-234. [CrossRef]

118. Gheldof, N.; Wang, A.X.-H.; Engeseth, N.J. Buckwheat Honey Increases Serum Antioxidant Capacity in Humans. J. Agric. Food Chem. 2003, 51, 1500-1505. [CrossRef]

119. Anand, S.; Pang, E.; Livanos, G.; Mantri, N. Characterization of Physico-Chemical Properties and Antioxidant Capacities of Bioactive Honey Produced from Australian Grown Agastache rugosa and its Correlation with Colour and Poly-Phenol Content. Molecules 2018, 23, 108. [CrossRef] [PubMed]

120. Adgaba, N.; Al-Ghamdi, A.; Sharma, D.; Tadess, Y.; Alghanem, S.M.; Khan, K.A.; Ansari, M.J.; Mohamed, G.K.A. Physicochemical, antioxidant and anti-microbial properties of some Ethiopian mono-floral honeys. Saudi J. Biol. Sci. 2020, 27, 2366-2372. [CrossRef] [PubMed]

121. Mărgăoan, R.; Topal, E.; Balkanska, R.; Yücel, B.; Oravecz, T.; Cornea-Cipcigan, M.; Vodnar, D. Monofloral Honeys as a Potential Source of Natural Antioxidants, Minerals and Medicine. Antioxidants 2021, 10, 1023. [CrossRef]

122. Karabagias, I.K.; Karabagias, V.K.; Gatzias, I.; Riganakos, K.A. Bio-Functional Properties of Bee Pollen: The Case of “Bee Pollen Yoghurt". Coatings 2018, 8, 423. [CrossRef]

123. Kieliszek, M.; Piwowarek, K.; Kot, A.; Błażejak, S.; Chlebowska-Śmigiel, A.; Wolska, I. Pollen and bee bread as new health-oriented products: A review. Trends Food Sci. Technol. 2018, 71, 170-180. [CrossRef] 
124. Aylanc, V.; Tomás, A.; Russo-Almeida, P.; Falcão, S.; Vilas-Boas, M. Assessment of Bioactive Compounds under Simulated Gastrointestinal Digestion of Bee Pollen and Bee Bread: Bioaccessibility and Antioxidant Activity. Antioxidants 2021, $10,651$. [CrossRef] [PubMed]

125. Didaras, N.; Kafantaris, I.; Dimitriou, T.; Mitsagga, C.; Karatasou, K.; Giavasis, I.; Stagos, D.; Amoutzias, G.; Hatjina, F.; Mossialos, D. Biological Properties of Bee Bread Collected from Apiaries Located across Greece. Antibiotics 2021, 10, 555 [CrossRef]

126. Boisard, S.; LE Ray, A.-M.; Gatto, J.; Aumond, M.-C.; Blanchard, P.; Derbré, S.; Flurin, C.; Richomme, P. Chemical Composition, Antioxidant and Anti-AGEs Activities of a French Poplar Type Propolis. J. Agric. Food Chem. 2014, 62, 1344-1351. [CrossRef]

127. Mujica, V.; Orrego, R.; Pérez, J.; Romero, P.; Ovalle, P.; Zuñiga, J.; Arredondo, M.; Leiva, E. The Role of Propolis in Oxidative Stress and Lipid Metabolism: A Randomized Controlled Trial. Evidence-Based Complement. Altern. Med. 2017, 2017, 4272940. [CrossRef]

128. Salmas, R.E.; Gulhan, M.F.; Durdagi, S.; Sahna, E.; Abdullah, H.I.; Selamoglu, Z. Effects of propolis, caffeic acid phenethyl ester, and pollen on renal injury in hypertensive rat: An experimental and theoretical approach. Cell Biochem. Funct. 2017, 35, 304-314. [CrossRef]

129. Jasprica, I.; Mornar, A.; Debeljak, Ž.; Smolčić-Bubalo, A.; Medić-Šarić, M.; Mayer, L.; Romić, Z.; Bućan, K.; Balog, T.; Sobočanec, S.; et al. In vivo study of propolis supplementation effects on antioxidative status and red blood cells. J. Ethnopharmacol. 2007, 110, 548-554. [CrossRef]

130. Dezmirean, D.S.; Paşca, C.; Moise, A.R.; Bobiş, O. Plant Sources Responsible for the Chemical Composition and Main Bioactive Properties of Poplar-Type Propolis. Plants 2020, 10, 22. [CrossRef]

131. Yosri, N.; El-Wahed, A.A.A.; Ghonaim, R.; Khattab, O.M.; Sabry, A.; Ibrahim, M.A.A.; Moustafa, M.F.; Guo, Z.; Zou, X.; Algethami, A.F.M.; et al. Anti-Viral and Immunomodulatory Properties of Propolis: Chemical Diversity, Pharmacological Properties, Preclinical and Clinical Applications, and In Silico Potential against SARS-CoV-2. Foods 2021, 10, 1776. [CrossRef]

132. Mesquita, R.D.C.G.; Franciscon, C.H. Flower Visitors of Clusia nemorosa G. F. W. Meyer (Clusiaceae) in an Amazonian White-Sand Campina. Biotropica 1995, 27, 254. [CrossRef]

133. Tomás-Barberán, F.A.; García-Viguera, C.; Vit-Oliviera, P.; Ferreres, F.; Tomás-Lorente, F. Phytochemical evidence for the botanical origin of tropical propolis from Venezuela. Phytochemistry 1993, 34, 191-196. [CrossRef]

134. Bankova, V. Recent trends and important developments in propolis research. Evid. Based Complement. Altern. Med. 2005, 2, 29-32. [CrossRef] [PubMed]

135. Montenegro, G.; Mujica, A.M.; Peña, R.C.; Gómez, M.; Serey, I.; Timmermann, B.N. Similitude pattern and botanical origin of the Chilean propolis. Phyton 2004, 73, 145-154.

136. Park, Y.K.; de Alencar, S.M.; Aguiar, C.L. Botanical Origin and Chemical Composition of Brazilian Propolis. J. Agric. Food Chem. 2002, 50, 2502-2506. [CrossRef] [PubMed]

137. López-Gutiérrez, N.; del Mar Aguilera-Luiz, M.; Romero-González, R.; Vidal, J.L.M.; Frenich, A.G. Fast analysis of polyphenols in royal jelly products using automated TurboFlow ${ }^{\mathrm{TM}}$-liquid chromatography-Orbitrap high resolution mass spectrometry. J. Chrom. B 2014, 973, 17-28. [CrossRef]

138. Liu, J.-R.; Yang, Y.-C.; Shi, L.-S.; Peng, C.-C. Antioxidant Properties of Royal Jelly Associated with Larval Age and Time of Harvest. J. Agric. Food Chem. 2008, 56, 11447-11452. [CrossRef]

139. Guo, H.; Kouzuma, Y.; Yonekura, M. Structures and properties of antioxidative peptides derived from royal jelly protein. Food Chem. 2009, 113, 238-245. [CrossRef]

140. Pourmoradian, S.; Mahdavi, R.; Mobasseri, M.; Faramarzi, E.; Mobasseri, M. Effects of royal jelly supplementation on glycemic control and oxidative stress factors in type 2 diabetic female: A randomized clinical trial. Chin. J. Integr. Med. 2014, 20, 347-352. [CrossRef]

141. Mohamed, A.A.-R.; Galal, A.; Elewa, Y.H. Comparative protective effects of royal jelly and cod liver oil against neurotoxic impact of tartrazine on male rat pups brain. Acta Histochem. 2015, 117, 649-658. [CrossRef] [PubMed]

142. Aslan, A.; Cemek, M.; Buyukokuroglu, M.E.; Altunbas, K.; Bas, O.; Yurumez, Y. Royal jelly can diminish secondary neuronal damage after experimental spinal cord injury in rabbits. Food Chem. Toxicol. 2012, 50, 2554-2559. [CrossRef]

143. Xue, X.; Wu, L.; Wang, K. Chemical Composition of Royal Jelly. In Bee Products-Chemical and Biological Properties; Springer Science and Business Media, LLC: Berlin, Germany, 2017; pp. 181-190.

144. Souto, E.B.; Silva, G.F.; Dias-Ferreira, J.; Zielinska, A.; Ventura, F.; Durazzo, A.; Lucarini, M.; Novellino, E.; Santini, A. Nanopharmaceutics: Part I-Clinical Trials Legislation and Good Manufacturing Practices (GMP) of Nanotherapeutics in the EU. Pharmaceutics 2020, 12, 146. [CrossRef] [PubMed]

145. Souto, E.B.; Silva, G.F.; Dias-Ferreira, J.; Zielinska, A.; Ventura, F.; Durazzo, A.; Lucarini, M.; Novellino, E.; Santini, A. Nanopharmaceutics: Part II-Production Scales and Clinically Compliant Production Methods. Nanomaterials 2020, 10, 455. [CrossRef]

146. Neupane, B.P.; Chaudhary, D.; Paudel, S.; Timsina, S.; Chapagain, B.; Jamarkattel, N.; Tiwari, B.R. Himalayan honey loaded iron oxide nanoparticles: Synthesis, characterization and study of antioxidant and antimicrobial activities. Int. J. Nanomed. 2019, 14, 3533-3541. [CrossRef]

147. Sarhan, W.A.; Azzazy, H.M. High concentration honey chitosan electrospun nanofibers: Biocompatibility and antibacterial effects. Carbohydr. Polym. 2015, 122, 135-143. [CrossRef] [PubMed]

148. Durazzo, A.; Lucarini, M.; Plutino, M.; Lucini, L.; Aromolo, R.; Martinelli, E.; Souto, E.B.; Santini, A.; Pignatti, G. Bee Products: A Representation of Biodiversity, Sustainability, and Health. Life 2021, 11, 970. [CrossRef] 
149. De Carvalho, F.M.d.A.; Schneider, J.K.; de Jesus, C.V.F.; de Andrade, L.N.; Amaral, R.G.; David, J.M.; Krause, L.C.; Severino, P.; Soares, C.M.F.; Caramão Bastos, E.; et al. Brazilian Red Propolis: Extracts Production, Physicochemical Characterization, and Cytotoxicity Profile for Antitumor Activity. Biomolecules 2020, 10, 726. [CrossRef]

150. De Mendonça, M.A.A.; Ribeiro, A.R.S.; De Lima, A.K.; Bezerra, G.B.; Pinheiro, M.S.; De Albuquerque-Júnior, R.L.C.; Gomes, M.Z.; Padilha, F.F.; Thomazzi, S.M.; Novellino, E.; et al. Red Propolis and Its Dyslipidemic Regulator Formononetin: Evaluation of Antioxidant Activity and Gastroprotective Effects in Rat Model of Gastric Ulcer. Nutrients 2020, 12, 2951. [CrossRef] [PubMed]

151. Ali, A.M.; Kunugi, H. Propolis, Bee Honey, and Their Components Protect against Coronavirus Disease 2019 (COVID-19): A Review of In Silico, In Vitro, and Clinical Studies. Molecules 2021, 26, 1232. [CrossRef] [PubMed] 